\title{
Reply to “Response to: Dittrich et al.: Non-Embryo-Destructive Extraction of Pluripotent Embryonic Stem Cells - Overlooked Legal Prohibitions, Professional Legal Consequences and Inconsistencies in Patent Law"
}

Antwort auf die „Replik zu: Dittrich et al.: Embryonenerhaltende Gewinnung pluripotenter Stammzellen übersehene strafrechtliche Verbote, berufsrechtliche Konsequenzen und patentrechtliche Inkonsequenzen“

Authors

Affiliations

\section{R. Dittrich ${ }^{1}$, M. W. Beckmann ${ }^{1}$, W. Würfel ${ }^{2}$}

${ }^{1}$ Frauenklinik des Universitätsklinikums Erlangen, Friedrich-Alexander Universität Erlangen-Nürnberg, Erlangen, Germany

${ }^{2}$ Kinderwunsch-Centrum München, München, Germany
Deutsche Version unter: http://dx.doi.org/ $10.1055 / \mathrm{s}-0042-116545$
Bibliography

Dol http://dx.doi.org/

$10.1055 / \mathrm{s}-0042-116545$

Geburtsh Frauenheilk 2016; 76 :

1308-1309 ๑ Georg Thieme

Verlag KG Stuttgart · New York . ISSN 0016-5751

\section{Correspondence}

Prof. Dr. rer. nat. Ralf Dittrich

Professur für exp.

Reproduktionsmedizin

Frauenklinik

Universitätsklinikum Erlangen

Universität Erlangen-Nürnberg

Universitätsstraße 21-23

91054 Erlangen

Germany

ralf.dittrich@uk-erlangen.de
In the spirit of productive scientific discussion we would like to start by thanking Faltus and Storz [1] for their comments.

We have studied them carefully and would like to add the following comments from our perspective:

1. Faltus and Storz were correct in stating that the German Embryo Protection Act (Embryonenschutzgesetz, ESchG) and the expansion of some of its points in the German Preimplantation Diagnosis Act (Präimplantationsgesetz, PräImpG) do not specify whether biopsies can be taken of cells from the inner cell mass (ICM) or whether biopsies should be trophectoderm biopsies (TEB). But the choice of biopsy must depend on which procedure is medically advisable and reasonable. All other considerations must be subordinate. In particular, legal considerations cannot define the choice of medical technique.

Biopsies of the inner cell mass (ICM) could soon become an important topic, as increasing numbers of publications are raising doubts about whether the chromosomal findings following the trophectoderm biopsies always mirror the genetics of the ICM, i.e., whether they might be offering false-negative results.

Should these doubts be confirmed on a large scale, then biopsies of the ICM would indeed represent the "approach of choice", as otherwise embryos with an intact genetic configuration will be discarded because the findings of the TEB came to a different conclusion.

2. Based on numerous publications on carrying out preimplantation genetic diagnosis (PIGD) on Day 3, an approach that is widely used outside Germany, we know that the extraction of 2 of 8 blastomeres can be done without complications and does not represent a "risk to the existence" of the embryo.
The patented method discussed here focuses on a later period of embryonic development, namely on Days 5/6 when the cells have already differentiated into different cell types and can therefore no longer be considered as totipotent. Why and wherefore this would entail a "risk to the existence" of the embryo at this point - and to a far higher degree than at an earlier and more critical point in time - is incomprehensible. At no point did we claim that this method is $100 \%$ safe. Nevertheless, the data from studies carried out abroad into biopsies performed on Day 3 show that even with this method the "risk to the existence" of the embryo must be assessed as low.

3. The authors went on to state: "The non-embryodestructive extraction of pluripotent stem cells from the inner cell mass ... is prohibited in Germany, and violations could result in criminal prosecution ... These procedures are not permitted as they are not conducive to preserving the embryo." [1].

We discussed preimplantation therapy (PIT) as a potential area where the patent could be used, i.e., conditions in which genetically anomalous cells could be "repaired" in vitro to allow the embryo to become viable. Under these circumstances the method could preserve more embryos than is currently the case. Used in this context the method is closer to the aims of the Embryo Protection Act, and given this premise we do not understand why the route described by Faltus and Storz where the embryo is "simply" [1] not transferred would be the likely choice.

We were writing, quite correctly, about a method which anticipated potential future developments, although it should be noted that the CRISPR-Cas method already describes a technique which is moving closer to such a "repair". 
This shows that already now the patent is not "looking ahead to a far distant future" [1] but has anticipated a development where technical implementation will occur much faster than one might think.

4. The authors also asked "... what 'market' would exist for nonembryo-destructive stem cell harvesting." [1].

The objective of filing this patent was not primarily its commercialization. No objection can (hopefully) be made that the aim of the patent was not commercialization.

5. The pregnancy rates following TEB of blastocysts are - even according to the initial reports from German PIGD centers and also in accordance with the literature - much higher, and current expected pregnancy rates are over $50 \%$ per embryo transfer. In this respect the stated $15 \%$ per IVF cycle are not correct (and they also do not correspond to the mean figures in the German IVF registry [DIR]); the figures for IVF treatments can probably not be simply transferred as the PIGD patient population is quite different and has specific genetic problems. Moreover this patient population does not generally suffer from fertility problems.

Whether a couple - when faced with the specific situation will consent to the extraction of cells from the inner cell mass if the procedure is not already medically indicated (see above) does not have to be the subject of legal or academic debate. The intention of the Embryo Protection Act was that couples would be informed about the advantages and disadvantages and that the women - and not her physician - would make the decision herself.

6. All of the described areas of application, whether as part of preimplantation therapy (PIT) or another therapy, are methods which are clearly covered in Germany by the ESchG or the PräImpG. It simply makes no sense to carry out such biopsies without carrying out genetic screening. And this is where the statutory provisions come into play. It is very clear that these applications are not operating in a legal vacuum but instead, in accordance with the current legal guidelines, have to be put to an ethics committee which must vote on the application.

7. The authors are of the opinion that the German patent DE 102004062184 B4 should not have been issued and that it runs a high "risk of being repealed". They stated that their opinion was based on the ruling in Case C-34/10 (Oliver Brüstle v Greenpeace $\mathrm{eV}$ ) by the European Court of Justice (ECJ) and the ruling (X ZR 58/07 - Neural Precursor Cells II) by the German
Federal Court of Justice (BGH) [1]. As Faltus and Storz correctly noted, the ECJ judgment has considered the meaning of the term "utilization of human embryos", and the BGH (which originally referred the question to the ECJ following which this ruling by the ECJ was handed down) uses this interpretation. The more recent parthenotes judgment (C-364/13) has given a more specific meaning to previous judgments. The German Patent and Trademark Office (DPMA) and the Federal Patent Court of Germany are bound by this interpretation.

In the present case, the decision by the German Supreme Court had already been taken into account in the patent application made to the DPMA, and the patent in question was therefore granted.

The authors are of course free to rate the BGH ruling as "not comprehensible". At all events, the neutral DPMA has assessed the ruling of the Supreme Court rather differently.

The parallel European patent application was rejected for formal reasons (impermissible modifications). This is of no importance for the existing patent protection in Germany and from a legal point of view has no impact on the validity of the German patent.

In summary, we wish to state that, in our view, the existing patent attempts to expand the spirit of the Embryo Protection Act, that is, the protection of the embryo both during its embryonic life and during its later life after birth.

We very much welcome a scientific discussion of this issue. However, we think it is a pity that much play was made here of "impressions" and much use was made of the subjunctive tense. Even if such assessments may be right, it is inherently difficult to argue against subjective perceptions.

\section{Conflict of Interest}

$\nabla$

R. D. and M. W. B. declare that they have no conflicts of interest. W. W. declares that he is the holder of patent DE 102004062 184 B4.

\section{References}

1 Faltus T, Storz U. Response to: Dittrich et al.: Non-embryo-destructive extraction of pluripotent embryonic stem cells - overlooked legal prohibitions, professional legal consequences and inconsistencies in patent law. Geburtsh Frauenheilk 2016; 76: 1302-1307 